\title{
THE AMATEUR IN ART
}

$\mathrm{W}^{\mathrm{E}}$ had been talking about the recent exhibitions and everybody agreed that it was a melancholy thing to see how men who had begun as real and sincere artists had, for obvious reasons, become purveyors of popular pictures. Another spoke of the work of a gifted and restless politician who was known to be in his spare moments a slashing painter of landscape. From this we came by a natural transition to amateurs generally and their ways.

Alison, the poet, contended strongly for the essential superiority of the amateur as a sort of aristocrat who was entitled to special consideration because he worked from inspiration while others worked by routine. Look at the daily articles, the weekly reviews, the annual novels. Look at the painters. 'Look' he said, ' at the average production here and abroad, at the Academy, the galleries, the Salons. Routine work without inspiration. Potboilers. Things done, not because they had to be done, but because something must be done. Fellows always at it - starve if they didn't, I am afraid, some of them. (Alison has a substantial income of his own). How can you have freshness of vision, spontaneity, sincerity, the things that make Art vital? How does the fun of the thing come in? No fun at all, drudgery. You know, Howard, what Schiller said about the element of play in Art-a sort of sublime-or at any rate charming-play in which we escape from the trammels of everyday life... The Amateur is the man who cannot, who will not forget this idea of play. $\mathrm{He}$ isn't chained to the car.' 


\section{Blackfriars}

'That is all very well, Alison,' said Howard, the critic, 'but can a man do good work on such easy terms? Can he dispense with the accomplishment that comes solely from incessant practice? Your amateur, whatever his inspiration or talent, cannot possibly have the craftsmanship of the man who is always at it.'

'He doesn't need to be always at it. Having the idea clear and bright in the mind is the essential thing. The rest comes easily once you have got that. Croce has shown conclusively that the essential artist is not your laborious craftsman but the inspired thinker, the man who develops his idea fully and perfectly in his mind and therefore becomes able to express it. Technique is nothing, Howard, nothing, without the clear and shining idea which must exist internally before the technique can give it external expression.'

' Then the technique, or as much of it as you may happen to require, comes of itself at the right moment?'

' It is not so much that it comes of itself as that it is called in to play by the formative energy of the idea. The idea brings the technique with it, and to that extent, technique is subordinate.'

'It is subordinate, or rather, I should say, secondary, but you minimise its importance. I hold it to be absolutely necessary and indispensable to the expression of the idea. My experience is that your amateur fails simply because he hasn't got it -or got enough of it.'

'I don't quite agree there,' I said. 'Some amateurs seem to possess an unholy power of making the very utmost of a little streak of talent they possess. They must do it by clever technique, for they certainly have none of the undisciplined wealth of imagination you seem to contemplate.' 


\section{The Amateur in Art}

'Personally,' replied Howard, 'I should be disposed to call such men occasional or lazy professionals, or rather, experts, which is the true antithesis of amateur.'

'Yes,' said Fleming, 'you import the idea of money into the matter and blur the distinction when you use the word "professional." It seems to me certain, however, that the only safe definition of "amateur" is the man who does not make a thing his occupation. But this is leading us away from the point which is, that inspiration brings technique with it-at least so I understand Alison.'

'Take your own case, Alison,' said MacDermott, who writes verses for the Saturday Westminster and sometimes gets a prize. 'When you conceive a poem, do you mean to tell us that you have the whole thing complete in your mind down to the last syllable before you put anything on paper? Doesn't the sestet of a sonnet, for instance, ever give you trouble?'

'It very often does,' Alison admitted. 'But what I want you to recognise is this. The amateur is the man who would naturally do the best work, but he refuses to pervert his talent to base uses, to fulfil coin missions, to write on prescribed subjects or paint to order, at the bidding of stupid people or commercial people, or for that matter, of any sort of people at all.'

'It seems to me,' said Fleming, ' that its just like politics or business. You've got to be determined to succeed. A man mustn't keep on asking himself whether it is worth while and all other paralysing questions about the meaning or value of his efforts. He should set to work and proceed to write or paint, or do whatever he wants. He should make an effort of will, pour out his soul, and so achieve his deliverance.'

'But, my dear Fleming,' said Howard, 'you are begging the question. That's just what your amateur would like to do, but can't. He would like to fling 


\section{Blackfriars}

off some little masterpiece every now and then without slaving at his art in between and all the while. But that's just what nobody can do. Even genius takes infinite pains, though infinite pains don't make genius. No, conception and execution are very far apart sometimes. If to conceive the idea were the same as to find fitting expression for it, in the appropriate medium, believe me, there would be a great deal more Art in the world than there is or than there is ever likely to be.'

'No,' continued Howard, ' this is precisely what the amateur cannot do. He cannot do his best. He cannot give his thought adequate expression. Why not? Because he lacks not so much the essential creative and selective sense as the technical equipment that training places at the artist's service. He may have the vision; but to communicate it is the prerogative of the Artist. It is in working things out that the Amateur realises his inferiority. As he approaches, the vision recedes; he tries to get at close quarters, and to his inexpressible dismay it eludes him. $\mathrm{He}$ is tormented by his inabilty to handle the medium by which alone the vision is communicable. $\mathrm{He}$ had counted upon it to obey him. In the first rapture of his inspiration he had thought it so plastic-but it suddenly becomes intractable. After wrestling with the task, he becomes involved in increasing difficulties, he begins to doubt the value of his original conception, to think it not worth while. Presently he finds that what he has produced falls everywhere short of his ideal. Self-criticism becomes acute and he relinquishes the ungrateful task. He did not shirk it in the first instance, as Fleming seems to think; he has tried to do his best, tried and failed.'

Macdermott nodded approval.

'The failure of the Amateur is the result of want of technique and want of practice. The professional, 380 


\section{The Amateur in Art}

the expert, has learnt his technique, is fortified by practice. He is accustomed to think in terms of his art and knows instinctively how to handle his medium. Art is not altogether an affair of inspiration, though there is no art without it; craftsmanship also is indispensable.

'You mean to say,' said Alison, 'that the amateur - - r the sort of amateur we seem to be discussingruins his own ideas because he can't express them properly? That is the gist of the matter?'

'Yes, that is the root of the matter; the Amateur encounters heart-breaking difficulties and eventual failure because he lacks technical equipment. On the other hand, the trained craftsman mechanically picks up the right tools and futs them to the right use, even when his heart is not in his work; how else do we get the journeyman work in art and fiction and the weekly article of an even standard of merit, the annual novel and the pot-boiling picture that we cannot fling a stone at because, whatever it may lack in passion or insight, it is technically irreproachable?

To be an amateur is to be occasional; the expert is always at work. The great poets, as you know, were always making verses; they made hundreds of verses that were never written down; as Tennyson said, "They went up the chimney." That is, they were always thinking in terms of their Art. Another thing that the Amateur heeds not is the methodical and incessant accumulation of material. The painter sees a cerfain effect; the writer thinks of "a good thing"; and each instantly frames his impression in words or sketch, and the record goes down in his note book for use at some time or other. Constant practice tells; he develops a cunning that becomes instinctive and his powers of expression grow pari passu with his receptive faculties. Consequently the expert can, like a skilful cook, make the most of odds and ends that the 


\section{Blackfriars}

Amateur would disdain; and the Amateur, whose occasional inspiration is perhaps of richer quality, is tortured to find that he cannot use it.'

'That,' said MacDermott with conviction, 'is absolutely, painfully true.'

'In manipulating and economising his material,' resumed Howard, 'the expert has resources that the Amateur never dreams of. There are hundreds of devices that to the uninitiated would seem incompatible with the clarity and purity of the artist's vision; but they are means to the end, which is their raison d'être and their justification. Triumphant art conceals the machinery that helps to produce it. The expert knows how to lighten the drudgery of composition by a dozen labour-saving devices. If the first and third paragraphs of his essay won't come, he leaves them and writes the second and fourth, or he may write them separately and independently, having his own secret for stringing them together. Look at Pater, for instance, with his special sentences written on separate slips of paper. The practised writer has his recipe for converting proverb into paradox and other people's epigrams into his own. He knows how to lay down the framework of a stanza or a sonnet and deftly fixes his last rhyme without losing any of the fire of his inspiration. He works over his draft again and again without ever a doubt of the effect he means to secure. But your Amateur does none of these things.

'I mean to say, therefore, that the Amateur, who relies upon inspiration and neglects technique, is not an artist, he is only artistic. The difference is very great, far too great to be veiled by a single syllable, for it is a difference in kind, not in degree. And in the light of this difference, once we clearly apprehend it, we see one of the deeper reasons for the compara- 
The Amateur in Art

tive failure of so many who begin well. How many of them are artistic, how few are artists!'

'I daresay,' said Fleming pensively, 'I daresay. But until we can define our terms and agree upon the definitions, like the Schoolmen, we shall never really know what we are talking about!'

J. J. DWYER. 